\title{
АБРЕВІАТУРИ В АНГЛОМОВНІЙ ТЕРМІНОСИСТЕМІ ОХОРОНИ ДОВКІЛЛЯ
}

\author{
Мар'яна Саламаха \\ Львівський національний університет імені Івана Франка, \\ вул. Університетська, 1, м. Львів, Україна, 79000 \\ e-mail:mysalamakha@ukr.net
}

\begin{abstract}
Абревіація $€$ продуктивним способом утворення термінів охорони довкілля. У статті виявлено, що з-поміж 2565 відповідних термінів 264 вживаються у скороченій формі. Абревіатури охорони довкілля охарактеризовано згідно зі структурним і семантичним критеріями. З'ясовано, що основна кількість абревіатур представлена ініціальною абревіацією, тобто складанням назв перших літер компонентів термінологічного словосполучення, оскільки вона легше піддається процесу інтеграції. Найчисельнішою у досліджуваному корпусі $є$ група трилітерних абревіатур. Щодо кількісних параметрів, то простежено певну тенденцію, коли зі збільшенням кількості літер в абревіатурі кількість останніх зменшується. Виокремлено шість основних лексико-семантичних груп абревіатур охорони довкілля. Найчастіше вони використовуються на позначення назв установ та організацій, а також назв документів, актів, законів тощо.

Ключові слова: абревіатура, алфавітизм, літерні абревіатури, лексико-семантична група, терміносистема охорони довкілля.
\end{abstract}

Вступ. Дослідження феномену абревіації у лінгвістиці зумовлене зацікавленням мовознавців до термінологічних систем з метою виявлення загальних закономірностей їхнього розвитку. Охорона довкілля - досить молода галузь, оскільки гострі проблеми довкілля 3'явились лише у XX-му столітті. Вивчення абревіатур терміносистеми охорони довкілля пояснюється зростаючим темпом міжнародної співпраці, необхідністю розуміння спеціалістів різних країн і подальшого розвитку наукових галузей.

Об'єкт дослідження - скорочення термінологічних словосполучень, які виявили частотність вживання та продуктивність у сфері охорони довкілля. Мета дослідження - описати особливості абревіатур досліджуваної термінології та виявити їхні типи.

Аналіз останніх досліджень і публікацій. Суттєвий внесок у дослідження абревіатур та їхньої класифікації зробила низка дослідників: О. С. Ахманова [1], В. Г. Гак [2], І. А. Потапова [10], О. П. Шаповалова [11], В. Н. Шевчук [12], А. Штайнхауер [17], В. Флейшер [15] та ін. Вивченням абревіатур різних англомовних терміносистем займались Е. Т. Дерді (юридичні абревіатури) [3], Ю. А. Завгороднсв (абревіатури фінансів та економіки) [4], О. М. Іващишин (абревіатури техногенного впливу на довкілля) [5], 3. Б. Куделько (абревіатури ринкових взаємин) [9] тощо. Проте абревіатури

(C) Саламаха М., 2019 
охорони довкілля досі не були предметом окремого дослідження. Отже, у цій статті здійснено першу спробу аналізу вищезгаданих абревіатур.

Абревіаційний спосіб термінотворення забезпечує потребу спілкування за рахунок конденсації інформації в комунікативних цілях і підвищення інформаційної цінності. Це зумовлено мовними, культурно-історичними та комунікативними чинниками $[8$, c. 50$]$.

Абревіатура - це одиниця письмового чи усного мовлення, яка створена з окремих елементів графічної чи звукової оболонки вихідної (початкової) повної форми (слова чи словосполучення), з якою ця одиниця знаходиться в певному лексико-семантичному зв'язку [7, с. 10].

Тенденція до скорочення термінів охорони довкілля зумовлена позамовними та мовними чинниками, пов'язаними з активізацією проблем довкілля. Внутрішньомовний чинник абревіації зумовлений мовною економією. Абревіатурам як повноправним одиницям вторинної номінації властиві номінативна здатність, входження у формальноструктурні, парадигматичні та синтагматичні зв'язки, семантичний розвиток, можливість зміни лексичного значення у діахронному аспекті тощо.

Скорочення матеріальної оболонки термінів чи термінологічних словосполучень сприяє швидкості їх сприйняття. Отже, абревіатури дають можливість економити не тільки час вимови мовної одиниці, а й артикуляційні зусилля того, хто говорить чи моторні зусилля того, хто пише [8, с. 43]. Абревіатури виконують функцію економії місця і в текстах. Через значне збільшення інформації, сфери охорони довкілля зокрема, виникає бажання скоротити обсяг фахових текстів, що стало можливим завдяки введенню в них абревіатур, які, зберігаючи інформативну насиченість, є доступними та зрозумілими для спеціалістів певної галузі. Іншими словами, в абревіатурах інформація передається меншою кількістю знаків, причому об'єм кожного знака такий самий як у відповідних первинних одиницях [14].

На структуру скорочених чи абревіаційних термінів впливають певні обмежувальні чинники: 1) фонетичний (оскільки для утворення абревіатур використовуються здебільшого такі елементи початкового словосполучення, які легко і зручно вимовляти); 2) морфологічний (адже структура абревіатури визначається морфологічною структурою початкової одиниці) та 3) семантичний (абревіатура повинна викликати асоціативні зв'язки, i, навпаки, уникати небажаних асоціацій) [7, с. 9].

Методологія дослідження. Матеріалом для аналізу та вивчення абревіатур охорони довкілля стали 264 абревіатури, відібраних методом суцільної вибірки із 7 фахових словників [18-24] та фахових статей (із журналу “Journal of Environmental Protection”) [25], загальним обсягом 4940 сторінок, опублікованих за 2010 - 2017 pp.

Методологія дослідження абревіатур охорони довкілля включає загальнофілософську, загальнонаукову та лінгвістичну методологію. До загальнонаукових методів належать методи, які використовуються для теоретичного та емпіричного дослідження: аналіз, індукція, дедукція, спостереження, опис, порівняння, узагальнення, класифікація тощо. Лінгвістична методологія, яка перебуває у тісному зв’язку із загальнонауковою, передбачає використання спеціальних лінгвістичних методів дослідження з метою розв'язання конкретних завдань. 
У процесі аналізу абревіатур використано такі лінгвістичні методи, як метод суцільної вибірки, метод аналізу словникових дефініцій, метод кількісних підрахунків і структурний методи.

Метод суцільної вибірки передбачає дефініційний або тезаурусний аналіз, який застосовується для уточнення дефініцій. Оскільки кожна абревіатура є скороченою версією повноцінного терміна чи термінологічного словосполучення, для їхнього аналізу за семантичним критерієм, поділу на лексико-семантичні групи та встановлення між ними семантичного зв'язку використано словникові дефініції термінологічних словосполучень. Основним із методів, що використовується для дослідження семантичних інваріантних та диференційних ознак, $є$ компонентний аналіз. В основі компонентного аналізу лежить припущення, що значення містить відносно невелику кількість семантичних ознак (сем), які є загальновідомими для всіх представників конкретного соціуму [6, с. 18]. Усі семантичні елементи у слові не є однаково важливими. Один (або кілька) з них є домінантним семантичним елементом і організовує навколо себе усі інші, які можуть бути більш або менш важливими для значення лексеми [16, c. 89]. Отже, різні компоненти у структурі терміна неоднакові за своїм значенням.

Відповідно, розрізняємо різні види сем - загальні та всі інші, що їм підпорядковані. Конкретнішими є власне лексичні семи, серед яких також виокремлюємо головні (категоріально-лексичні семи) та залежні (підпорядковані). Виявлення однакових спільних категоріально-лексичних сем у структурі значень термінів уможливило їхню класифікацію на лексико-семантичні групи, для позначення яких найчастіше використовуються абревіатури.

За допомогою методів спостереження, опису, порівняння та узагальнення проаналізовано структурні особливості абревіатур та здійснено класифікації згідно зі структурою.

Отримані висновки щодо аналізу абревіатур охорони довкілля підтверджуються кількісними підрахунками, які здійснено на основі конкретних класифікацій, що дало змогу глибше та детальніше описати структурні та семантичні особливості абревіатур досліджуваної терміносистеми.

Результати дослідження та їхнс обгрунтування. Синтаксичний спосіб утворення термінів охорони довкілля засвідчив досить високу активність утворення абревіатур. Використання абревіатур у фахових текстах та комунікації є однією з ознак опанування відповідної термінології та професійного мовлення.

Особливістю термінів-абревіатур є те, що всі вони є варіантами термінологічних словосполучень: ISCLT (Industrial Source Complex Long Term model) - “довготермінова модель (забруднення повітря) промислового комплексу як суцільного джерела викидів”; MEA (Master Environmental Assessment) - “основна оцінка довкілля”.

Аналіз 264 абревіатур уможливив виявлення таких структурних типів:

1) ініціальні абревіатури (ініціалізми), які поділяємо на:

а) акроніми, тобто такі, що вимовляються за початковими звуками компонентів термінологічного словосполучення, тобто як одне слово [13, с. 57]. Виявлено 26 акронімів: LIDAR (Light Detection and Ranging) - “лазерний засіб виявлення та стеження (за частинками забруднювачів повітря, викидами промислових споруд)"; 
NOW (Nonhazardous Oil Field Waste) - “безпечні відходи нафтового родовища”; SOC (Synthetic Organic Chemical Contaminant) - “штучна органічна хімічна забруднювальна речовина";

б) літерні, які утворюються 3 початкових літер компонентів термінологічних словосполучень. Для позначення ініціальних абревіатур літерного типу використовуємо термін “алфавітизм”, запроваджений О. П. Шаповаловою [11, с. 58]. Наше дослідження засвідчило, що аналізована терміносистема характеризується переважно алфавітизмами. Це підтверджує наш висновок, що літерний спосіб абревіації є найпоширенішим способом утворення термінів-абревіатур як варіантів вихідного термінологічного словосполучення: HSL (Hazardous Substance List) - “список небезпечних речовин”; HLW (High-level Waste) - “відходи високої радіоактивності”; ISR (Indirect Source Review) - “оцінка непрямих джерел забруднення повітря”;

2) комбіновані абревіатури утворюються поєднанням слова чи його частини із літерами, звуками або цифрами. У досліджуваній терміносистемі здебільшого зустрічаємо комбіновані абревіатури, які у своїй структурі містять алфавітизм або акронім та слово: AI test (Adsorption Isotherm Test) - “проба ізотермічного поглинання хімічних речовин грунтом"; $\boldsymbol{H W M}$ facility (Hazardous Waste Management Facility) - “центр устаткування для переробки небезпечних матеріалів"; HEPA filter (HighEfficiency Particulate Air Filter) - “високоефективний сухий макрочастинковий очищувач повітря".

Виявлено випадки, коли абревіатури отримують граматичні ознаки іменника. Особливо це стосується утворення множини за допомогою закінчення -s після абревіатури: VOCs (Volatile Organic Contaminants) - “забруднювальні леткі органічні речовини”; POHCs (Principal Organic Hazardous Constituents) - “основні органічні небезпечні складові компоненти"; CFCs (chlorofluorocarbons) - “хлорофторвуглецеві сполуки".

Аналіз абревіатур терміносистеми охорони довкілля засвідчує, що ініціальна літерна абревіація представлена такими структурними типами:

1) однолітерна абревіація репрезентована поодинокими прикладами зазвичай на позначення назв величин і хімічних сполук (які вважаємо номенклатурними знаками): $\boldsymbol{K}$ (carrying capacity of the environment) - “потенційна місткість екосистеми”; $\boldsymbol{P}$ (power) - "потужність";

2) дволітерна абревіація (33 терміни): $\boldsymbol{O G}$ (organic gas) - “органічний газ; $\boldsymbol{P F}$ (protective factor) - “коефіцієнт захисту”; QF (quality factor) - “показник якості”. Крім того, дві букви часто позначають назви хімічних речовин чи сполук: $\boldsymbol{C O}$ (carbon monoxide) - "монооксид вуглецю";

3) трилітерна абревіація охорони довкілля представлена найбільшою кількістю 3 усіх типів, що свідчить про їхню частотність у досліджуваній терміносистемі (117 термінів): EPA (Environmental Protection Agency) - “агентство охорони довкілля”; $\boldsymbol{R D F}$ (Refuse-derived Fuel) - "паливо, добуте із відходів"; $\boldsymbol{M E A}$ (Master Environmental Assessment) - “основна оцінка довкілля"; $\boldsymbol{M S W}$ (Municipal Solid Waste) - "міські побутові тверді відходи”; TSD (Treatment, Storage or Disposal) - “обробка, зберігання або усування (небезпечних відходів)"; 
4) чотирилітерна абревіація представлена 57 термінами (з 264 абревіатур): $\boldsymbol{A Q R V}$ (Air Quality Related Value) - “відносна якість повітря"; CAER (Community Awareness and Emergency Response) - "громадська обережність та реагування на непередбачений випадок”; IPIT (Index of Potential Inhalation Toxicity) - “коефіціент можливості інгаляційного отруєння”; $\boldsymbol{S W M U}$ (Solid Waste Management Unit) - “ділянка землі для обробки твердих відходів";

5) $\boldsymbol{n}$ 'ятилітерна абревіація налічує 36 термінів і свідчить про те, що зі збільшенням кількості літер в абревіатурах, частотність їх вживання падає: CHRIS (Chemical Hazard Response Information System) - “інформативна система реакції на потенційно-небезпечні хімічні аваріï”; LOAEL (Lowest Observed Adverse Effect Level) - “найнижча ефективна шкідлива доза (найменша доза хімічного забруднення, при якій спостерігається шкідливий наслідок)".

Кількісні дані щодо використання літерної абревіації наведено в таблиці (табл. 1): Таблиия 1

Кількісна репрезентація літерної абревіації охорони довкілля

\begin{tabular}{|l|c|c|c|c|c|c|c|}
\hline Абревіатури & $\begin{array}{c}\text { Одно- } \\
\text { літерні }\end{array}$ & $\begin{array}{c}\text { Дво- } \\
\text { літерні }\end{array}$ & $\begin{array}{c}\text { Три- } \\
\text { літерні }\end{array}$ & $\begin{array}{c}\text { Чотири- } \\
\text { літерні }\end{array}$ & $\begin{array}{c}\text { П'яти- } \\
\text { літерні }\end{array}$ & $\begin{array}{c}\text { Шести- } \\
\text { та семи- } \\
\text { літерні }\end{array}$ & Усього \\
\hline Кількість & 3 & 33 & 97 & 57 & 36 & 12 & 264 \\
\hline Відсоток & $1,2 \%$ & $14 \%$ & $40,8 \%$ & $24 \%$ & $15 \%$ & $5 \%$ & $100 \%$ \\
\hline
\end{tabular}

Кількісно-відсоткова вживаність вищезазначених типів абревіатур не є однаковою в досліджуваній терміносистемі. Трилітерні абревіатури $є$ найчисельнішими, а однолітерні є поодинокими, що пояснюється можливим позначенням однолітерною абревіатурою кількох предметів одночасно, адже кількість букв в англійському алфавіті $\epsilon$ обмеженою. П'яти- та шестилітерні абревіатури також не представлені кількісно, оскільки, відповідно, не є великою кількість термінологічних словосполучень, що складаються з п'яти та шести компонентів. Різноманітна кількість поєднань трьох літер і пояснює велику кількість абревіатур саме цих типів.

Крім того, зустрічаємо абревіатури, в яких перший скорочений елемент словосполучення поєднується 3 повною формою основного терміна. Це так звані “телескопічні слова", тобто частково скорочені слова типу K-value (Multi-purpose Dilution Safety Factor) - “універсальний коефіцієнт безпечності розрідження”, чи H-bomb (Hydrogen Bomb) - “воднева бомба". Також до телескопічних слів належить термін smog, що утворений з двох слів - smoke+fog.

Дослідження абревіатур охорони довкілля також дало можливість здійснити їхню класифікацію за семантичним критерієм, унаслідок чого було виокремлено шість лексико-семантичних груп. Абревіатури охорони довкілля найчастіше позначають:

1) назви установ та організацій (75 абревіатур). У досліджуваній терміносистемі вони представлені переважно три-, чотири- та п'ятилітерними абревіатурами: $\boldsymbol{A P C A}$ (Air Pollution Control Association) - “Асоціація контролю за забрудненням повітря”; 
$\boldsymbol{C E Q}$ (Council on Environmental Quality) - “рада у справах якості довкілля”; IUCN (International Union for Conservation of Nature and Natural Resources) - “міжнародне об'єднання зберігання природи та природних ресурсів";

2) назви документів, актів та законів (60): CAA (Clean Air Act) - “Акт про чистоту повітря"; EIR (Environmental Impact Report) - “Звіт про вплив на довкілля”; OPA (Oil Pollution Act) - “Закон про забруднення нафтою”;

3) назви стандартів, необхіднх для підтримання довкілля у належному стані, програм, спрямованих на охорону довкілля (52): СЕРP (Chemical Emergency Preparation Program) - “програма готовності до хімічних аварійних ситуацій”; CARP (Countdown Acid Rain Program) - “програма поточного обліку кислотного дощу”; NAAQS (National Ambient Air Quality Standards) - "Національні стандарти якості оточуючого повітря";

4) назви обладнання, пристроїв для очищення та запобігання проблем довкілля (38): POTWs (Publicly Owned Treatment Works) - “громадська споруда очищення стічних вод”; WWT (Wastewater Treatment Plant) - “завод обробки стічної води”;

5) назви систем та методів запобігання проблем довкілля (24): GEMS (Global Environment Monitoring System) - “система глобального нагляду за довкіллям”; HACS (Hazard Assessment Computer System) - “комп”ютерна система оцінювання загроз для довкілля";

6) назви величин (10): BOD (Biological Oxygen Demand) - “біологічна потреба в кисні”; $\boldsymbol{A C H}$ (Air Change per Hour) - “повітряний обмін за годину”; $\boldsymbol{R M C L}$ (Recommended Maximum Contaminant Level) - "рекомендований максимальний рівень забруднюючої речовини".

Отже, найчастіше абревіатури охорони довкілля використовуються на позначення “назв установ і організацій” та “назв документів, актів, законів”.

Висновки та перспективи подальших досліджень. Абревіація $є$ поширеним способом формування термінів охорони довкілля, причому такі номінації є завжди вторинними за своєю природою, оскільки утворюються завдяки скороченню, усіченню чи зведенню до початкових літер від уже наявних термінів, а найчастіше, термінологічних словосполучень. Зменшуючи довжину термінологічного словосполучення, абревіатури залишають за собою повне інформативне навантаження, а також компактно, доступно та зрозуміло передають необхідну інформацію серед фахівців. Завдяки економії мовних засобів та передаванню ємної інформації абревіатури здобули велику популярність у текстах сфери охорони довкілля. За допомогою абревіації досліджувана сфера поповнюється новими лексичними одиницями, причому для позначення одного і того ж поняття використовуються дві повноцінні мовні форми - термінологічне словосполучення та абревіатура, яка виступає його коротким варіантом.

Аналіз 264 абревіатур здійснено згідно з структурним та семантичним критеріями. Досліджувана терміносистема характеризується ініціальними літерними абревіатурами, тобто складанням назв перших літер компонентів термінологічного словосполучення. У своїй структурі абревіатури охорони довкілля можуть містити від однієї до шести та більше букв. Щодо кількісних параметрів простежується певна тенденція: найбільшою виявилася група трилітерних абревіатур, причому із збільшенням кількості літер в абревіатурі, кількість їх зменшується, що пояснюється меншою 
кількістю термінологічних словосполучень, до складу яких входять чотири та більше компонентів.

Виокремлено шість основних лексико-семантичних груп абревіатур охорони довкілля, серед яких абревіатури найчастіше позначають “назви установ і організацій” та “назви документів, актів, законів”.

Вивчення абревіації як одного із способів термінотворення сприятиме опису та впорядкуванню терміносистеми сфери охорони довкілля в цілому. Перспективи подальших розвідок вбачаємо у розгляді таких способів утворення термінів охорони довкілля, як запозичення та неономінація.

\section{СПИСОК ВИКОРИСТАНОЇ ЛІТЕРАТУРИ}

1. Ахманова О. С. Очерки по общей и русской лексикологии / О. С. Ахманова. - М. : Гос. Учебно-пед. изд. Министерства просвещения РСФСР, 1957. - 295 с.

2. Гак В. Г. Языковые преобразование : монография / В. Г. Гак. - М. : Школа: Языки русской культуры, 1998. - 764 с.

3. Дерді Е. Т. Словотвірні та структурно-семантичні характеристики англійських юридичних термінів : автореф. дис. на здобуття наук. ступеня канд. філол. наук : спец. 10.02.04 "Германські мови" / Е. Т. Дерді. - К., 2003. - 21 с.

4. Завгороднєв Ю. А. Способи утворення фінансово-економічних термінів у сучасній англійській мові / Ю. А. Завгороднєв, О. І. Дуда // Іноземна філологія. - Львів, 1999. - Вип. 111. - С. 201-207.

5. Іващишин О. М. Англійські термінологічні словосполучення у текстах 3 проблем техногенного впливу на довкілля : автореф. дис. на здобуття наук. ступеня канд. філол. наук : спец. 10.02.04 “Германські мови” / О. М. Іващишин. - Львів, 2007. - 20 с.

6. Ковалик Н. В. Смислотвірні та прагматико-функціональні особливості лексеми service в англійських економічних і юридичних текстах : автореф. дис. на здобуття наук. ступеня канд. філол. наук : спец. 10.02.04 “Германські мови” / Н. В. Ковалик. - Львів, 2010. -22 c.

7. Кочарян Ю. Г. Аббревиация в английской военной лексике : автореф. дис. на соиск. учен. степени канд. филол. наук : спец. 10.02.04 “Германские язики” / Ю. Г. Кочарян. - М., 2007. - 21 c.

8. Криворот В. В. Особенности аббревиации в русском, английском и французском языках / В. В. Криворот // Язык, речь, общение в контексте диалога языков и культур : сб. науч. тр. ; отв. ред. О. И. Уланович. - Мн. : Изд. центр БГУ, 2012. - С. 42-50.

9. Куделько 3. Б. Англійська терміносистема ринкових взаємин: синтагматичні та парадигматичні особливості : дис. ... канд. філол. наук : 10.02.04 / Куделько Зоя Борисівна. - Чернівці, 2003. - 243 с.

10. Потапова И. А. Сокращения в современном английском языке / И. А. Потапова // Уч. зап. 1-го Лен. гос. пединститута иностр. языков. Нов. сер. - 1955. - Вып. 2. C. 99-115.

11. Шаповалова А. П. Опыт построения общей теории аббревиаций (на материале французских сокращенных лексических единиц) : дис. ... д-ра филол. наук : 10.02.19 / Шаповалова Александра Петровна. - Ростов-на-Дону, 2004. - 421 с.

12. Шевчук В. Н. Относительно статуса аббревиатур в английском языке и их перевода на русский язик / В. Н. Шевчук // Система языка и перевод. - М. : МГУ. - 1983. C. $120-130$.

13. Шелов С. Д. Определение терминов и понятийная структура терминологии / С. Д. Шелов. - СПб., 1998. - 234 с. 
14. Яковлева С. А. Сокращения как лингвистическая особенность ветеринарных терминов (на материале английского языка) // Magister Dixit. 2011. № 4. С. 36-40.

15. Fleischer W. Wortbildung der deutschen Gegenwartssprache / Wolfgang Fleischer. - Leipzig : VEB Bibliographisches Institut, 1969. - $327 \mathrm{~S}$.

16. Lyons J. Linguistic semantics: An introduction / John Lyons. - Cambridge : Cambridge University Press, 1995. $-376 \mathrm{p}$.

17. Steinhauer A. Sprachökonomie durch Kurzwörter: Bildung und Verwendung in der Fachkommunikation / Anja Steinhauer. - Tübingen : Narr, 2000. - 371 S.

\section{СПИСОК ВИКОРИСТАНИХ ДЖЕРЕЛ}

18. Lee C. C. Environmental Engineering Dictionary / C. C. Lee. - Government Institutes, 2005. $-968 \mathrm{p}$.

19. Matthews J. A. The Encyclopaedic Dictionary of Environmental Change / J. Anthony Matthews. - London, 2003. - 690 p.

20. McGraw-Hill. Dictionary of Environmental Science / McGraw-Hill. - New York, 2005. $496 \mathrm{p}$.

21. Pfafflin P. J. The Dictionary of Environmental Science and Engineering / P. James Pfafflin, M. Joseph Lynch. - London, 2008. - 280 p.

22. Seidel E. Dictionary of Environmental Protection Technology: in four languages: English, German, French, Russion / Egon Seidel. - Amsterdam ; New Hork : Elsevier, 1988. $527 \mathrm{p}$.

23. Stevenson L. H. Dictionary of Environmental Science / L. Harold Stevenson, Bruce Wyman. - New York, 1991. - 402 p.

24. Terms of the Environment: Glossary, Abbreviations and Acronyms [Electronic resource]. Access mode : http://infohouse.p2ric.org/ref/ 01/00402.htm

25. Journal of Environmental Protection. - Scientific Research Publishing. Inc. USA [Electronic resource]. - Access mode : www.scirp.org/journal/jep/

\section{REFERENCES}

1. Ahmanova O. S. Ocherki po obshhej i russkoj leksikologii [Essays on General and Russian Lexicology] / O. S. Ahmanova. - M. : Gos. Uchebno-ped. izd. Ministerstva prosveshhenija RSFSR, 1957. - $295 \mathrm{~s}$.

2. Gak V. G. Jazykovye preobrazovanie [Language transformations] : monografija / V. G. Gak. - M. : Shkola: Jazyki russkoj kul’tury, 1998. - 764 s.

3. Derdi E. T. Slovotvirni ta strukturno-semantychni kharakterystyky anhliiskykh yurydychnykh terminiv [Word-forming and structural-semantic characteristics of English legal terms]: avtoref. dys. na zdobuttia nauk. stupenia kand. filol. nauk : spets. 10.02.04 "Hermanski movy" / E. T. Derdi. - K., 2003. - 21 s.

4. Zavhorodniev Yu. A. Sposoby utvorennia finansovo-ekonomichnykh terminiv u suchasnii anhliiskii movi [Methods of formation of financial and economic terms in modern English] / Yu. A.Zavhorodniev, O. I. Duda // Inozemna filolohiia. - Lviv, 1999. - Vyp. 111. - S. 201-207.

5. Ivashchyshyn O. M. Anhliiski terminolohichni slovospoluchennia u tekstakh z problem tekhnohennoho vplyvu na dovkillia [English terminological phrases in texts on the problems of man-made environmental impact]: avtoref. dys. na zdobuttia nauk. stupenia kand. filol. nauk : spets. 10.02.04 "Hermanski movy" / O. M. Ivashchyshyn. - Lviv, 2007. - 20 s.

6. Kovalyk N. V. Smyslotvirni ta prahmatyko-funktsionalni osoblyvosti leksemy service $\mathrm{v}$ anhliiskykh ekonomichnykh i yurydychnykh tekstakh [Meaningful and pragmatic- 
functional features of the lexeme service in English economic and legal texts]: avtoref. dys. na zdobuttia nauk. stupenia kand. filol. nauk : spets. 10.02.04 "Hermanski movy" / N. V. Kovalyk. - Lviv, 2010. - 22 s.

7. Kocharjan Ju. G. Abbreviacija v anglijskoj voennoj leksike [Abbreviation in English military vocabulary]: avtoref. dis. na soisk. uchen. stepeni kand. filol. nauk : spec. 10.02.04 "Germanskie jaziki" / Ju. G. Kocharjan. - M., 2007. - 21 s.

8. Krivorot V. V. Osobennosti abbreviacii v russkom, anglijskom i francuzskom jazykah [Features of abbreviation in the Russian, English and French languages] / V. V. Krivorot // Jazyk, rech', obshhenie v kontekste dialoga jazykov i kul'tur : sb. nauch. tr. ; otv. red. O. I. Ulanovich. - Mn. : Izd. centr BGU, 2012. - S. 42-50.

9. Kudelko Z. B. Anhliiska terminosystema rynkovykh vzaiemyn: syntahmatychni ta paradyhmatychni osoblyvosti [The English terminology of market relations: syntagmatic and paradigmatic features] : dys. ... kand. filol. nauk : 10.02.04 / Kudelko Zoia Borysivna. - Chernivtsi, 2003. - 243 s.

10. Potapova I. A. Sokrashhenija v sovremennom anglijskom jazyke [Acronyms in Modern English] / I. A. Potapova // Uch. zap. 1-go Len. gos. pedinstituta inostr. jazykov. Nov. ser. 1955. - Vyp. 2. - S. 99-115.

11. Shapovalova A. P. Opyt postroenija obshhej teorii abbreviacij (na materiale francuzskih sokrashhennyh leksicheskih edinic) [The experience of constructing a general theory of abbreviation (based on French abbreviated lexical units) ] : dis. ... d-ra filol. nauk : 10.02.19 / Shapovalova Aleksandra Petrovna. - Rostov-na-Donu, 2004. - $421 \mathrm{~s}$.

12. Shevchuk V. N. Otnositel'no statusa abbreviatur v anglijskom jazyke $i$ ih perevoda na russkij jazik [Regarding the status of abbreviations in English and their translation into Russian] / V. N. Shevchuk // Sistema jazyka i perevod. - M. : MGU. - 1983. - S. 120-130. 13. Shelov S. D. Opredelenie terminov i ponjatijnaja struktura terminologii [Definition of terms and conceptual structure of terminology] / S. D. Shelov. - SPb., 1998. - $234 \mathrm{~s}$.

14. Jakovleva S. A. Sokrashhenija kak lingvisticheskaja osobennost' veterinarnyh terminov (na materiale anglijskogo jazyka) [Abbreviations as a linguistic feature of veterinary terms (based on the English language)] // Magister Dixit. 2011. \# 4. S. 36-40.

15. Fleischer W. Wortbildung der deutschen Gegenwartssprache / Wolfgang Fleischer. - Leipzig : VEB Bibliographisches Institut, 1969. - $327 \mathrm{~S}$.

16. Lyons J. Linguistic semantics: An introduction / John Lyons. - Cambridge : Cambridge University Press, 1995. - 376 p.

17. Steinhauer A. Sprachökonomie durch Kurzwörter: Bildung und Verwendung in der Fachkommunikation / Anja Steinhauer. - Tübingen : Narr, 2000. - 371 S.

\section{SOURCES}

18. Lee C. C. Environmental Engineering Dictionary / C. C. Lee. - Government Institutes, 2005. $-968 \mathrm{p}$.

19. Matthews J. A. The Encyclopaedic Dictionary of Environmental Change / J. Anthony Matthews. - London, 2003. - 690 p.

20. McGraw-Hill. Dictionary of Environmental Science / McGraw-Hill. - New York, 2005. - 496 p.

21. Pfafflin P. J. The Dictionary of Environmental Science and Engineering / P. James Pfafflin, M. Joseph Lynch. - London, 2008. - 280 p.

22. Seidel E. Dictionary of Environmental Protection Technology: in four languages: English, German, French, Russion / Egon Seidel. - Amsterdam ; New Hork : Elsevier, 1988. - 527 p. 
23. Stevenson L. H. Dictionary of Environmental Science / L. Harold Stevenson, Bruce Wyman. - New York, 1991. - $402 \mathrm{p}$.

24. Terms of the Environment: Glossary, Abbreviations and Acronyms [Electronic resource].Access mode : http://infohouse.p2ric.org/ref/ 01/00402.htm.

25. Journal of Environmental Protection. - Scientific Research Publishing. Inc. USA [Electronic resource]. - Access mode: www.scirp.org/journaljep/.

\title{
ABBREVIATIONS IN THE TERMINOLOGICAL SYSTEM OF ENVIRONMENTAL PROTECTION
}

\section{Maryana Salamakha}

\author{
Ivan Franko National University of Lviv, \\ 1, Universystetska Str., Lviv, Ukraine, 79000 \\ e-mail:mysalamakha@ukr.net
}

In the article an attempt has been made to analyze English Environmental Protection (EP) abbreviations. It should be noted that abovementioned abbreviations have not yet been studied. Therefore, the paper offers the first full description and classification of English Environmental Protection abbreviations. Among $2565 \mathrm{EP}$ terms, selected from EP and ecological dictionaries as well as scientific articles from the "Journal of Environmental Protection" during the period of 2011-2018 years (5653 pages), 264 abbreviations have been identified, this proving that abbreviation is a common way of forming EP terms. Such nominations are always secondary in their nature as they are formed by shortening, contraction or clipping to initial letters of already existing terms or, most often, terminological phrases. Due to abbreviations, the sphere under study is enriched with new lexical units. Therefore, for denoting the same concept, two full-fledged linguistic forms are used - a terminological phrase and an abbreviation, which is its short version. The popularity of abbreviations is obviously justified: by shortening their external form, i.e. by economizing linguistic and space resources, they still contain the entire information load and convey it to professionals in a concise and clear way.

All the EP abbreviations have been classified according to structural and semantic criteria. The analysis has shown that the terminological system under research is characterized by initial letter abbreviations, i.e. the compilation of the first letters of terminological phrase components. According to their structure, EP abbreviations contain from one to six or more letters. The most numerous group of EP abbreviations is presented by those consisting of three letters. A certain trend has been defined: with the increase in the number of letters in an abbreviation, the number of such abbreviations decreases, which can be explained by a smaller number of terminological phrases comprising four or more components. The group of abbreviations consisting of only one letter is also very small.

The method of componential analysis allowed classifying EP abbreviations according to a semantic criterion. Therefore, six thematic groups have been determined. Most often, abbreviations refer to the names of establishments and organizations or names of documents, laws and acts.

The study of abbreviations as a way of term-formation is extremely important since it facilitates the description of the terms and thus contributes to the research of EP terminological system.

Key words: abbreviation, alphabetism, letter abbreviations, lexical-semantic group, environmental protection terminological system. 